\author{
Maxim, C., Drivers of Success in Implementing Sustainable Tourism Policies in \\ Urban Areas, Tourism Planning and Development, DOI: \\ 10.1080/21568316.2014.960599
}

\title{
Drivers of Success in Implementing Sustainable Tourism Policies in Urban Areas
}

\begin{abstract}
The existing literature in the field of sustainable tourism highlights a number of barriers that impede the implementation of policies in this area. Yet, not many studies have so far considered the factors that would contribute to putting this concept into practice, and few address the case of urban areas. The concept of sustainability has only received limited attention in urban tourism research, even though large cities are recognized as one of the most important tourist destinations that attract vast numbers of visitors. Adopting a case study approach, this paper discusses a number of drivers of success identified by policy makers in London to contribute to the implementation of sustainable tourisms policies at local level, and briefly looks at the relationship between these drivers and the constraints perceived by the respondents to hinder the implementation of such policies in practice. These findings may help policy makers in other large cities to successfully develop and implement policies towards sustainable development of tourism in their area.
\end{abstract}

Keywords: drivers of success, urban tourism, sustainable tourism implementation, London

\section{Introduction}

Over the last few decades, sustainable development has become something of a buzzword (Liu, 2003; Singh, 2012), and has been considered by numerous policy documents and plans, as well as research publications. Consequently, sustainable tourism - generally perceived as a "positive approach" to tourism development (Bramwell \& Lane, 1993, p.2) - has been adopted by many managers of tourist destinations, and has become part of the public agenda. This is also highlighted by Weaver (2011), who notes that "since the mid-1990s, discourses about the tourism sector have become increasingly dominated, at least rhetorically, by the ideas and ideals of sustainability" (p.5). Therefore, the concept has been promoted by researchers and organisations as a possible solution to minimise the negative 
consequences that accompany tourism development in a region, while also maximising its positive influences (Connell \& Page, 2008; Ruhanen, 2008; UNWTO, 2004). Moreover, it is believed that sustainable tourism can contribute towards a balance between the different interests of stakeholders involved in tourism activities, while helping to protect the environment (Testoni, 2001; UNWTO, 2007).

However, despite its popularity, the concept of sustainability has received less attention in the context of urban tourism than in the case of other forms of tourism (Law, 2002; Timur \& Getz, 2008; UNWTO, 2004). One reason may be that the field of urban tourism is a relatively new area of research that has been previously overlooked by researchers (Ashworth \& Page, 2011), but which has lately attracted more attention due to the rapid growth seen by this form of tourism (Maitland, 2009). Another explanation could be that sustainable tourism is primarily associated with nature and environmental consequences, whereas in cities more visible are the economic and socio-cultural impacts of tourism. In this respect, although a number of authors argue that large cities could absorb considerable numbers of tourists "without obvious repercussions" (Wall \& Mathieson, 2006, p.207), other critics have pointed out a series of negative impacts of urban tourism, such as overcrowding, an increase in existing congestion and air pollution, overuse of facilities, or conflicts between the interests of tourists and those of the local community (Law, 2002; Popp, 2012; Sharpley \& Roberts, 2005).

Furthermore, over the past years many authors have highlighted that despite the support portrayed by governments for sustainable tourism, in practice there is still a large discrepancy between policy endorsements and the reality of its implementation (Dodds \& Butler, 2009; 2010; Liburd \& Edwards, 2010; Moyle et al., 2014). This is also underlined by Sharpley (2009) and Butler (2010) who note that even though governments adopted with much enthusiasm the ideologies of sustainable tourism, so far little evidence of real action can be seen. Indeed, the implementation of sustainability principles in the tourism sector is considered more complex than in the case of other industries due to the different interests and needs of the main stakeholders involved in tourism development - residents, visitors, the public sector and the tourism industry (Dwyer \& Edwards, 2010). This complex process requires various issues to be managed at the same time, and there is no "ultimate recipe" to guarantee a successful implementation of sustainable tourism policies in practice (Farsari, Butler, \& Szivas, 2011, p.1130). As a result, a number of studies have tried to understand the issues faced by destination managers and have highlighted a number of barriers that impede the implementation of sustainable tourism policies (e.g. Dodds \& Butler, 2010). However, not many studies have so far considered the factors that would contribute to putting this concept into practice, and few have addressed the case of urban environments. Therefore, to help fill this gap, the present paper discusses a number of drivers of success identified by policy makers in London to contribute to the implementation of sustainable tourism policies at local level. In this context, the term "drivers of success" encompasses those factors that have a positive influence on putting into practice policies that promote sustainable tourism development in a region. In addition, the study looks briefly at the constraints perceived by the policy makers in London to hinder the implementation of such policies, and whether there is a relationship between these factors and the drivers of success identified. The findings of this study could therefore help policy makers in other urban destinations to successfully develop and implement policies and strategies towards sustainable development of tourism in their area. 


\section{The Case Study - London}

As one of the largest cities in Europe and a world tourism city, London attracts around 15 million international visitors each year (GLA Economics, 2012). The capital is an important gateway for the UK, with three quarters of the visitors coming to the country staying in London for at least one night during their visit (LDA, 2009), and with over a quarter of all tourism expenditure in the country occurring in London (Office for National Statistics, 2014; data for year 2011). The city offers a large variety of attractions that cater to different categories of visitors with diverse interests (e.g. historic buildings, parks and promenade areas, cultural establishments, numerous restaurants, pubs and clubs). Some people may come to London to visit friends or relatives, others for business or education, and others simply for the authentic experience of being in such a colourful and diverse environment (Bull \& Church, 2001). In addition, the city plays multiple functions such as a centre of trade, a global financial centre, the home of national cultural institutions, and the seat of central government (Maitland \& Newman, 2009), all of which contribute to the large number of tourists it attracts every year. Over the past few years the capital also hosted a number of exceptional events that are expected to enhance its image and that of the UK worldwide, and therefore bring more tourists in the near future (i.e. the 2012 Olympic and Paralympic Games, The Queen's Diamond Jubilee in 2012, and the Royal Wedding in 2011).

Yet, even though London is one of the most visited cities in the world and tourism plays an important role for its economy (GLA Economics, 2012), there has been only limited research on the development of tourism in the capital, and even less on sustainable tourism. A possible reason may be that tourism was recognised only in the 1990s as an important contributor to the economy of the capital (Evans, 2000), when it started to be included in the development policies of local authorities. The most recent works in this field include those of Bull and Church (1996; 2001), Bull (1997), Long (2000), Evans (2000), and Maitland and Newman (2004; 2009). However, although these studies discuss different aspects of tourism development in London (for example inter-organisational collaboration for local tourism development, tourism policy development and tourism trends), none of them look at the sustainable development of this activity in the capital. But with the number of tourists expected to increase in the following years, and the number of residents projected to grow (Office for National Statistics, 2012), policy makers would need to consider suitable measures and strategies to accommodate more visitors in a sustainable manner, without disturbing the local community or damaging the built and natural environment. Therefore, this study identifies a number of factors perceived by the research participants to contribute to the successful implementation of sustainable tourism principles in practice, and which can help policy makers in their efforts to manage tourism development in a destination.

\section{Methodology}

In order to better understand the factors that influence the implementation of sustainable tourism polices in urban areas, London - a world tourism city - was chosen as an exploratory case study (Yin, 2009) for the present research. As mentioned earlier, London is one of the largest and most visited cities in Europe (GLA Economics, 2012), but which has been surprisingly neglected as a research subject with respect to sustainable tourism. Therefore, using London as a case study would contribute to understanding the factors that have a positive impact on the sustainable development of tourism in urban destinations. 
In terms of the data collection methods employed, an online survey was conducted with representatives of the 33 local authorities in London, which contributed to identifying the drivers of success in developing and implementing sustainable tourism policies at local level. Using open-ended questions for this particular aspect, the participants were given the option to specify any factors they thought would contribute to, or would impede the implementation of sustainable tourism measures in practice. This type of question allowed respondents to answer freely and to include rich information on the subject (Finn, Elliott-White, \& Walton, 2000). The data gathered through this research method was then complemented with data collected through a number of 23 semi-structured interviews conducted with representatives of public and private organisations involved in the development of tourism in the capital. In choosing the interview subjects, the snowball technique was considered to be the most suitable sampling tool for selecting the relevant organisations to be included in this research (Altinay \& Paraskevas, 2008; Berg, 2007). The analysis is therefore based on the survey responses received from the representatives of 31 local authorities (that answered the questionnaire) and is supplemented with rich data collected through the interviews. As the questions related to this topic that were included in the survey, as well as those in the interviews, were open ended, a general inductive qualitative approach (Thomas, 2006) was adopted for the data analysis. Accordingly, the answers were considered repeatedly so that a number of patterns could be extracted and appropriate categories (themes) identified. The data was then coded with the help of the NVivo software, "one of the most widely used" qualitative data analysis computer software packages (Veal, 2011, p.401), and examined in terms of differences and similarities between categories in order to identify relevant patterns and connections.

\section{Findings - Factors which Contribute to Sustainable Tourism Implementation}

The survey revealed several drivers of success considered by the participants to have an influence in developing and implementing sustainable tourism at the local level, and these can be divided into 14 groups (see Figure 1). The factors most often mentioned relate to stakeholder cooperation, partnership and support, and were indicated by nearly half of the survey participants. This group of drivers includes cooperation with other departments within the same local authority, with other local organisations that have an interest in tourism development, and with the tourism industry. The support offered by the local community and the tourism industry was also acknowledged by respondents as an important factor that contributes to achieving sustainable tourism in a destination. In addition, one of the participants noted that "sustainable development is so cross cutting, it can't be the responsibility of one single team/officer" (survey participant no. 12). This illustrates the complex nature of the two concepts, sustainable development and sustainable tourism, and achieving the latter requires a strong cooperation between multiple stakeholders involved in tourism development. The need for participation and cooperation of all relevant stakeholders in tourism is indeed underlined in relevant literature by several researchers and organisations (Dodds \& Butler, 2010; Lane, 2009; UNWTO, 2004; Williams \& Ponsford, 2009;). Furthermore, working in partnership was also identified by the representatives who took part in the interviews as one of the measures that should be taken in order to promote sustainable tourism in London.

The next group of drivers, identified by over a third of the survey respondents, consists of policies, strategies and plans for tourism development. This view is also supported by a number of organisations and researchers, who argue that in order to achieve sustainable tourism in a destination, local authorities would need to carefully plan and manage this phenomenon (Godfrey \& Clarke, 2000; 
Goeldner \& Ritchie, 2006; Inskeep, 1991; UNWTO, 2004). Apart from dedicated policies, strategies and plans to guide the development of tourism, the respondents mentioned the need for joined up policies, shared visions and objectives for tourism development, coordinated strategies that would link in with the main players in the tourism industry, and sustainable development policies that would apply to tourism development as well. Furthermore, the interview respondents underlined the need for a clear vision, policies, strategies and plans for the development of tourism in an area. In addition, one interviewee stressed that besides designing tourism policies, it is important that local authorities allocate the necessary resources to implement them in practice, which is an essential step towards achieving sustainable development of tourism in a destination.

Moving on, about a quarter of survey respondents considered that good public transport accessibility as well as other related infrastructure positively contributes to the development and implementation of sustainable tourism. Moreover, providing transport infrastructure and encouraging walking and cycling were also acknowledged by a number of interview respondents. Law (2002) is one of the researchers who underline the importance of good transport infrastructure, in particular in cities that attract many tourists where it also facilitates the transportation of visitors. In addition, Dodds and Butler (2010) identify transportation as one of the sectors which influence sustainable tourism policies, a consequence of the fact that transport is the main contributor to the $\mathrm{CO}_{2}$ emissions produced by the tourism industry (Gössling, Hall, \& Weaver, 2009), and that it also affects the quality of life for residents (DCMS, 2009).

Also about a quarter of survey respondents said that well known tourist attractions and visitor demand have a role to play in achieving sustainable tourism in a destination. Related to this, the representatives of four other local authorities indicated that marketing campaigns aimed at promoting the tourist offer in order to attract more tourists could also contribute to sustainable tourism. In the interviews however, none of the participants mentioned these two aspects, which are in fact aimed towards attracting more visitors to the area and thus are more to do with gaining economic benefits from tourism development rather than achieving sustainable tourism development in a destination.

Another driver of success identified by a small number of survey participants (about 16\%) is the availability of funding/resources to help in developing and implementing sustainable tourism. For example, one representative notes that "sustainable tourism policies need an advocate to ensure this area is resourced adequately" (survey participant no. 7), and that funding as well as well-trained people are available to help with its implementation. But for this to become reality, one interviewee believes that the non-governmental organisations and academia have a role to play in lobbying the government and the public sector to promote sustainable tourism. In the same time, this driver relates to political will which is mentioned by four survey participants, and which together with strong lead and commitment from senior decision-makers can help push forward the case for sustainable tourism. These two drivers of success were also identified by Dredge (2007) among the factors that influence tourism planning at the local level. Moreover, a number of organisations and researchers underline that sustainable tourism requires a strong political leadership, which would contribute in achieving consensus among all stakeholders involved in tourism development (Archer, Cooper, \& Ruhanen, 2005; Choi \& Sirakaya, 2006; UNWTO, 2004).

Furthermore, strong community support to develop tourism in the area and knowledge and understanding of the tourism industry were both considered (by 3 survey participants each) as a necessity to achieve sustainable tourism in a destination. Indeed, the attitude of the local community towards tourists and tourism development is very important when establishing local policies and determining the public support for tourism (Page \& Hall, 2003). Moreover, a number of researchers argue that the support and engagement of residents with tourism activities can contribute significantly 
to the success of a destination. On the other hand, knowledge and understanding of the tourism industry would help in adopting and implementing sustainable tourism initiatives in practice (Gössling et al., 2009). As noted by one interview respondent representing a tourism organisation, sometimes the government and the private sector "operate in two completely different mind sets and they need to work together to understand in practice how do you get this to work" (interview respondent no. 19).

In addition to those noted so far, there are a number of other factors identified by the interview respondents to contribute to the implementation of sustainable tourism policies in practice, and which were not mentioned by the survey participants. Two of these aspects were recognised by a large proportion of the interview respondents, and they are to promote education (both training and awareness) and legislation. In terms of education, the representatives noted that it is important for the tourism industry and visitors to understand what sustainable tourism is and what are the advantages of implementing this concept. This would help identify the sustainability issues faced by a destination, which in many cases differ from one place to another. Education is also one of the factors recognised by Getz and Timur (2005) as contributing to increasing sustainable tourism practices. Promoting legislation is another significant factor identified by several interviewees who consider that specific measures should be adopted in order to discourage negative behaviour and to protect the environment. Among the legislative tools mentioned by the respondents are standards, awards, incentives and penalties. Although government regulation is not favoured by the tourism industry, as noted by Kerr (2003), it may prove a way forward in order to successfully implement sustainable tourism policies at local level, a view also supported by a number of other researchers (Bramwell \& Lane, 2010; Hall, 2008; Pigram, 1992).

Finally, three other factors were mentioned by a few interview respondents: promoting best practices to highlight examples of projects that have been successful in implementing sustainable tourism; long term focus of local and central government in favour of a proactive planning and not just reaction to change; and introducing fee-charging attractions in order to limit visitor numbers, when necessary. Indeed, the lack of best practices in the field has also been underlined by JansenVerbeke and Lievois (1999), while a long term perspective is one of the principles identified by the European Commission (2007) to contribute to sustainable tourism development. However, Lew (2010) notes that although long term solutions are very necessary, these are the most difficult to project because the sustainability issues faced by a destination tend to change over time.

In order to gain a better understanding of these aspects, this paper looks briefly at whether there is a relationship between the drivers of success discussed and the constraints and limitations perceived by the research participants to hamper the implementation of sustainable tourism policies in practice. A first observation is that if the respondents identified a number of 14 drivers of success for the implementation of sustainable tourism polices at local level, in terms of constrains they only mentioned 8 groups of factors that impede the efforts of putting such policies in practice. Moreover, all these constraints and limitations, except for one - the lack of strong leadership - are the opposites of the drivers of success discussed earlier (i.e. lack of resources and funding; lack of knowledge and understanding of sustainable tourism; resistance of residents to increased visitor numbers; lack of political support; lack of effective partnership; lack of public transport infrastructure, and accessibility issues; lack of a tourism offer and well-known attractions). However, the number of policy makers who recognised the presence of these factors as drivers of success was different from the number of those who identified their absence as constraints. For example, stakeholder cooperation and partnership was the driver recognised by most respondents to contribute to the implementation of sustainable tourism policies, while only a few respondents saw the lack of it as a constraint or 
limitation. At the same time, the constraint noted by most policy makers to impede sustainable tourism implementation is the lack of resources and funding, which was identified by nearly half of the respondents, while only 5 survey participants mentioned funding and resources as a driver of success. Therefore, even though many factors identified to influence sustainable tourism policies at local level can be drivers of success, as well as constraints or limitations (when absent), it appears that the importance given to them in each of these two capacities is different - i.e. they are sometimes considered as drivers by more research participants, while fewer of them would name the same factor as a constraint, and vice versa. It should however be noted that this complex relationship between the factors influencing sustainable tourism implementation at local level may be different from one location to another, as each destination presents unique characteristics that are also likely to vary in time.

\section{Discussion and Conclusion}

The drivers of success identified in this study as contributing to the implementation of sustainable tourism policies include stakeholder cooperation and partnership; policies, strategies and plans for tourism development; good public transport accessibility; funding and other resources; political will; strong community support to develop tourism in their area; knowledge and understanding of the tourism industry; long term focus; promoting education on sustainable tourism; promoting legislation (e.g. awards, incentives and penalties); examples of best practices; and charging fees for attractions when needed, in order to limit visitor numbers. Some of these factors have been recognised in previous studies by different researchers (e.g. Lane, 2009; Law, 2002) and organisations (e.g. UNWTO, 2004) as important for achieving sustainable tourism in a destination. However, this research highlighted that there is a combination of drivers that may contribute to the successful implementation of sustainable tourism policies at local level, and their interaction should be carefully considered by policy makers. Based on the findings discussed in the previous section, a number of implications for policy makers when implementing sustainable tourism at local level are detailed further.

First of all, when planning tourism development in a destination, working in partnership with other organisations and consulting all stakeholders (including the tourism industry and the local community), would have a positive contribution to sustainable tourism implementation. This aspect is also noted by Veal (2010), who highlights the complex nature of the phenomenon of tourism and argues that achieving sustainable development of this activity would require a strong cooperation between the multiple stakeholders involved in its development. As noted earlier, sustainable tourism is about finding a balance between the conflicting interests of all stakeholders in tourism, which can often have different agendas (Dodds \& Butler, 2010). Therefore, developing partnerships with other organisations, both from the public and the private sector, could overcome possible conflicts and bring in more resources and expertise to help with the implementation of sustainable tourism policies. Furthermore, this approach is advised in the new tourism strategy for Britain, "Government Tourism Policy" (DCMS, 2011), where the private sector is encouraged to take responsibility and work in partnership with the local authorities in order to create Destination Management Organisations that would coordinate tourism development in an area.

In addition, if the positive impacts of tourism in a destination are to be maximized and the negative consequences kept to a minimum, local authorities need to develop policies and strategies, as well as to allocate the resources needed for planning and managing this activity. These two processes 
are considered essential for achieving sustainable development of tourism, as they can contribute to the conservation and regeneration of an area, to economic development, and to a better quality of life both for the communities and visitors (Archer et al., 2005; Connell, Page, \& Bentley, 2009). Yet, looking at London, over the past few years there has been a major reduction in human resources and budgets allocated by local authorities for the planning and management of tourism activities. This is most likely a consequence of the economic downturn that prompted deep budget cuts for the UK public sector, which resulted in a number of public organisations and units responsible with the development of tourism in the capital being either abolished or restructured (e.g. the London Development Agency, the main organisation responsible with the development of tourism in the capital, was abolished in March 2012). However, the lack of resources allocated for tourism, together with a lack of policies and strategies for the planning and management of this activity at local level could have significant negative consequences, particularly in the long term (e.g. damaging of the build and natural environment, leading to poor visitor experience and to a diminished quality of life for local residents). Therefore, investing the resources needed for planning and managing tourism in a destination could prevent major costs in future, caused by the negative impacts that can accompany an unsustainable development of this activity.

Furthermore, the need for policy makers and the tourism industry to have the knowledge and understanding of what sustainable tourism means and how it can be implemented in practice have also been highlighted in previous research. For example, Ruhanen (2008) recognises the need for further education on this subject and advocates for a knowledge management approach to help with translating the sustainable tourism principles in practice. Although up to date there is no widely accepted definition for sustainable tourism (Ruhanen, 2008) and its meaning depends on the sociocultural context where it evolves (Beaumont \& Dredge, 2010), each destination could agree on what this concept means in their particular case so that all stakeholders involved in the development of tourism in that area would be aware of it and could contribute towards achieving it.

Finally, political will (regardless of the political party in power) and making sustainability a priority for the development of tourism would help local authorities to allocate the necessary resources and to adopt the long-term measures needed to progress towards sustainable tourism. Yet, as a consequence of the economic difficulties, over the past years a change seems to have occurred from the sustainability discourse focused on long-term benefits (future generations), to a discourse favouring short-term measures for economic growth that are expected to lead to an economic recovery (Raco \& Street, 2012). Although economic growth is an important factor that contributes to the wellbeing of a population, it has been demonstrated since the 1970s that without considering the other two dimensions of sustainability - social and environmental - and trying to balance all these three aspects, a destination is unlikely to thrive in the long term. Therefore, sustainability needs to be high on the agenda of local and central government at all times and needs to be considered a priority for all types of development.

In conclusion, following a literature review it was observed that the implementation of sustainable tourism policies is still very limited in practice. Therefore, to help understand what are the factors that could contribute to a better implementation of such policies at local level this paper discussed a number of drivers of success identified by policy makers in London. Furthermore, it observed that part of these factors were noted in a previous study conducted by Dodds and Butler (2010) who looked at the constraints in the implementation of sustainable tourism policy in two Mediterranean mass tourism destinations. Therefore, it would seem that these factors are not only applicable to the particular case of London, but also to other destinations. Nevertheless, as the present study had an exploratory nature, further research would be needed to better understand and test the 
relationships between the drivers found to influence the sustainable tourism planning at local level, as well as to confirm whether they apply to other types of destinations. Moreover, further research should be conducted to determine the importance given to each of these factors, whether some of them would be more important than the others, or if they could be prioritised. This may help policy makers to line up their limited resources in accordance with the most important factors that need to be considered.

\section{References}

Altinay, L., \& Paraskevas, A. (2008). Planning Research in Hospitality and Tourism. Oxford: Elsevier.

Archer, B., Cooper, C., \& Ruhanen, L. (2005). The Positive and Negative Impacts of Tourism. In W. F. Theobald (Ed.), Global Tourism (pp.79-102). Burlington: Elsevier.

Ashworth, G.J., \& Page, S.J. (2011). Urban Tourism Research: Recent Progress and Current Paradoxes. Tourism Management, 32 (1),1-15.

Beaumont, N., \& Dredge, D. (2010). Local Tourism Governance: A Comparison of Three Network Approaches. Journal of Sustainable Tourism, 18 (1), 7-28.

Berg, B.L. (2007). Qualitative Research Methods for the Social Sciences (6th ed.). Boston: Pearson Education.

Bramwell, B., \& Lane, B. (2010). Sustainable Tourism and the Evolving Roles of Government Planning. Journal of Sustainable Tourism, 18 (1), 1-5.

Bramwell, B., \& Lane, B. (1993). Sustainable Tourism: An Evolving Global Approach. Journal of Sustainable Tourism, 1 (1), 1-5.

Bull, P. (1997). Tourism in London: Policy Changes and Planning Problems. Regional Studies, 31 (1), $82-85$.

Bull, P., \& Church, A. (1996). The London Tourism Complex. In C. M. Law (Ed.), Tourism in Major Cities (pp.155-178). London: International Thomson Business Press.

Bull, P., \& Church, A. (2001). Understanding Urban Tourism: London in the Early 1990s. International Journal of Tourism Research, 3 (2), 141-150.

Butler, R.W. (2010). Carrying capacity in tourism: paradox and hypocrisy? In R. W. Butler, \& D. Pearce (Eds.), Tourism Research: A 20:20 Vision (pp.53-64). Oxford: Goodfellow Publishers Limited.

Choi, H.C., \& Sirakaya, E. (2006). Sustainability Indicators for Managing Community Tourism. Tourism Management, 27 (6), 1274-1289.

Connell, J., \& Page, S.J. (2008). The Evolution and Development of Sustainable Tourism: Progress and Prospects. In S. J. Page \& J. Connell (Eds.), Sustainable Tourism: Critical Concept in the Social Sciences (pp.1-20). London: Routledge.

Connell, J., Page, S.J., \& Bentley, T. (2009). Towards Sustainable Tourism Planning in New Zealand: Monitoring Local Government Planning under the Resource Management Act. Tourism Management, 30 (6), 867-877.

DCMS. (2011). Government Tourism Policy. London: DCMS. Retrieved from: <http://www.culture.gov.uk/images/publications/Government2_Tourism_Policy_2011.pdf>.

DCMS. (2009). Sustainable Tourism in England: A Framework for Action - Meeting the Key Challenges. London: DCMS.

Dodds, R., \& Butler, R.W. (2010). Barriers to Implementing Sustainable Tourism Policy in Mass Tourism Destinations. Tourismos: An International Multidisciplinary Journal of Tourism, 5 (1), 35-53.

Dodds, R., \& Butler, R.W. (2009). Inaction more than Action: Barriers to the Implementation of Sustainable Tourism Policies. In S. Gössling, C. M. Hall, \& D. Weaver (Eds.), Sustainable Tourism Futures: Perspectives on Systems, Restructuring and Innovations (pp. 44-57). Abingdon: Routledge. 
Dredge, D. (2007). Local Destination Planning and Policy. In D. Dredge, \& J. Jenkins (Eds.), Tourism Planning and Policy (pp.300-335). Milton: John Wiley \& Sons.

Dwyer, L., \& Edwards, D. (2010). Sustainable Tourism Planning. In J. J. Liburd \& D. Edwards (Eds.) Understanding the Sustainable Development of Tourism (pp.19-44). Oxford: Goodfellow Publisher Limited.

European Commission. (2007). Agenda for a Sustainable and Competitive European Tourism. Retrieved from: <http://ec.europa.eu/enterprise/sectors/tourism/documents/communications/ commission-communication-2007/index_en.htm>.

Evans, G. (2000). Planning for Urban Tourism: A Critique of Borough Development Plans and Tourism Policy in London. International Journal of Tourism Research, 2 (5), 307-326.

Farsari, I., Butler, R.W., \& Szivas, E. (2011). Complexity in tourism policies: A Cognitive Mapping Approach. Annals of Tourism Research, 38 (3), 1110-1134.

Finn, M., Elliott-White, M., \& Walton, M. (2000). Tourism and Leisure Research Methods: Data Collection, Analysis, and Interpretation. Essex: Pearson Education Limited.

Getz, D., \& Timur, S. (2005). Stakeholder Involvement in Sustainable Tourism: Balancing the Voices. In W. F. Theobald (Ed.), Global Tourism (pp.230-247). Burlington: Elsevier.

GLA Economics. (2012). Tourism in London. Working Paper 53. Retrieved from: <http://www.london.gov.uk/sites/default/files/wp53.pdf>.

Godfrey, K., \& Clarke, J. (2000). The Tourism Development Handbook: A Practical Approach to Planning and Marketing. London: Thomson Learning.

Goeldner, C.R., \& Ritchie, J.R. (2006). Tourism: Principles, Practices, Philosophies (10th ed.). Hoboken: John Wiley \& Sons.

Gössling, S., Hall, C.M., \& Weaver, D. (2009). Sustainable Tourism Futures: Perspectives on Systems, Restructuring and Innovations. In S. Gössling, C. M. Hall, \& D. B. Weaver (Eds.), Sustainable Tourism Futures: Perspectives on Systems, Restructuring and Innovations (pp.115). Abingdon: Routledge.

Hall, C.M. (2008). Tourism Planning: Policies, Processes and Relationships (2nd ed.). Harlow, Pearson Education Limited.

Inskeep, E. (1991). Tourism Planning: An Integrated and Sustainable Development Approach. New York: John Wiley \& Sons.

Jansen-Verbeke, M., \& Lievois, E. (1999). Analysing Heritage Resources for Urban Tourism in European Cities. In D. Pearce, \& R. W. Butler (Eds.), Contemporary Issues in Tourism Development (pp.81-107). London: Routledge.

Kerr, W.R. (2003). Tourism Public Policy, and the Strategic Management of Failure. Oxford: Pergamon.

Lane, B. (2009). Thirty Years of Sustainable Tourism: Drivers, Progress, Problems and the Future. In S. Gössling, C. M. Hall, \& D. Weaver (Eds.), Sustainable Tourism Futures: Perspectives on Systems, Restructuring and Innovations (pp.19-32). Abingdon: Routledge.

Law, C.M. (2002). Urban Tourism: The Visitor Economy and the Growth of Large Cities (2nd ed.). London: Continuum.

LDA. (2009). London Tourism Action Plan 2009-13. Retrieved from: <http://www.lda.gov.uk/Documents/London_Tourism_Action_Plan_2009-13_6537.pdf>.

Lew, A.A. (2010). Time as a Major Barrier to Sustainable Development. Tourism Geographies, 12 (3), 481-483.

Liburd, J.J., \& Edwards, D. (2010). The Future of Sustainability. In J. J. Liburd, \& D. Edwards (Eds.), Understanding the Sustainable Development of Tourism. Oxford: Goodfellow Publishers Limited.

Liu, Z. (2003). Sustainable Tourism Development: A Critique. Journal of Sustainable Tourism, 11 (6), 459-475.

Long, P. (2000). Development Regimes in the City Fringe: The Case of Discover Islington, London. Journal of Sustainable Tourism, 8 (3), 190-206.

Maitland, R. (2009). Introduction: National capitals and city tourism. In: R. Maitland, \& B. W. Ritchie (Eds.), City Tourism: National Capital Perspectives (pp.1-13). Wallingford: CABI.

Maitland, R., \& Newman, P. (2004). Developing Metropolitan Tourism on the Fringe of Central London. International Journal of Tourism Research, 6 (5), 339-348. 
Maitland, R., \& Newman, P. (2009). London: Tourism Moving East? In R. Maitland, \& P. Newman (Eds.), World Tourism Cities: Developing Tourism Off the Beaten Track (pp.66-86). New York: Routledge.

Moyle, B.D., McLennan, C.J., Ruhanen, L., \& Weiler, B. (2014). Tracking the concept of sustainability in Australian tourism policy and planning documents. Journal of Sustainable Tourism, 22(7), 1-15

Office for National Statistics. (2012). Subnational Population Projections. Retrieved from: $<\mathrm{http} / / / \mathrm{www}$.ons.gov.uk/ons/rel/snpp/sub-national-population-projections/Interim-2011based/index.html $>$.

Office for National Statistics. (2014). The Regional Value of Tourism 2011. Retrieved from: <http://www.ons.gov.uk/ons/dcp171776_353069.pdf>.

Page, S.J., \& Hall, C.M. (2003). Managing Urban Tourism. Harlow: Pearson Education Limited.

Pigram, J.J. (1992). Alternative Tourism: Tourism and Sustainable Resource Management. In V. L. Smith, \& W. R. Eadington (Eds.), Tourism Alternatives: Potentials and Problems in the Development of Tourism (pp.76-87). Philadelphia: University of Pennsylvania Press.

Popp, M. (2012). Positive and Negative Urban Tourist Crowding: Florence, Italy. Tourism Geographies, 14 (1), 50-72.

Raco, M., \& Street, E. (2012). Resilience Planning, Economic Change and The Politics of Postrecession Development in London and Hong Kong. Urban Studies, 49 (5), 1065-1087.

Ruhanen, L. (2008). Progressing the Sustainability Debate: A Knowledge Management Approach to Sustainable Tourism Planning. Current Issues in Tourism, 11 (5), 429-455.

Sharpley, R. (2009). Tourism Development and the Environment: Beyond Sustainability? London: Earthscan Ltd.

Sharpley, R., \& Roberts, L. (2005). Managing Urban Tourism. In: L. Pender \& R. Sharpley (Eds.), The Management of Tourism (pp.161-174). London: SAGE.

Singh, T.V. (2012). Introduction. In: T. V. Singh (Ed.), Critical Debates in Tourism (pp.1-26). Bristol: Channel View Publications.

Testoni, L. (2001). Planning for Sustainable Tourism. Pacific Tourism Review, 4, 191-199.

Thomas, D.R. (2006). A General Inductive Approach for Analyzing Qualitative Evaluation Data. American Journal of Evaluation, 27 (2), 237-246.

Timur, S., \& Getz, D. (2008). A network perspective on managing stakeholders for sustainable urban tourism. International Journal of Contemporary Hospitality Management, 20 (4), 445-461.

UNWTO. (2007). A Practical Guide to Tourism Destination Management. Madrid: UNWTO.

UNWTO. (2004). Indicators of Sustainable Development for Tourism Destinations: A Guidebook. Madrid: UNWTO.

Veal, A.J. (2010). Leisure, Sport and Tourism: Politics, Policy and Planning (3rd revised ed.). Wallingford: CABI Publishing.

Veal, A.J. (2011). Research Methods for Leisure and Tourism: A Practical Guide (4th ed.). Harlow: Prentice Hall.

Wall, G., \& Mathieson, A. (2006). Tourism: Change, Impacts and Opportunities. Harlow: Pearson Education.

Weaver, D. (2011). Can sustainable tourism survive climate change? Journal of Sustainable Tourism, 19 (1), 5-15.

Williams, P., \& Ponsford, I.F. (2009). Confronting Tourism's Environmental Paradox: Transitioning for Sustainable Tourism'. Futures, 41 (6), 396-404.

Yin, R.K. (2009). Case Study Research: Design and Methods (4th ed.). London: Sage Publications 
Figure 1 Drivers of success in developing and implementing ST policies at local level

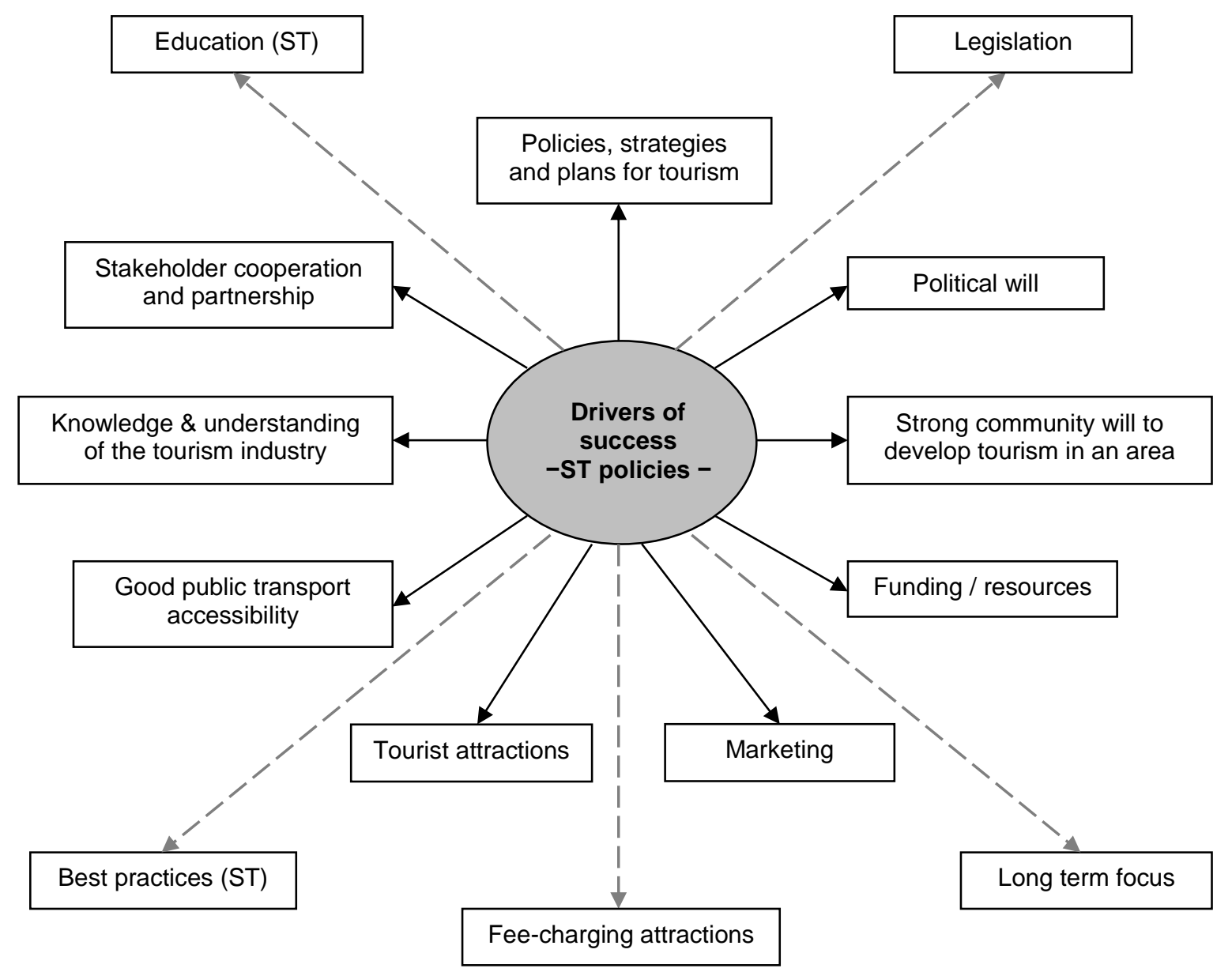

\section{Legend}

Drivers identified by the survey participants and interview respondents

$-\rightarrow$ Other drivers identified by the interview respondents 